\title{
Effects of Milk Feeding Strategy and Acidification on Growth Performance, Metabolic Traits, Oxidative Stress, and Health of Holstein Calves
}

\author{
Gibson Maswayi Alugongo ${ }^{1}$, Jianxin Xiao ${ }^{1}$, Arash Azarfar ${ }^{2}$, Shuai Liu ${ }^{1}$, \\ Mohammed Husien Yousif ${ }^{1}$, Yulin Ma ${ }^{1}$, Yangjing Wang ${ }^{1}$, Shengli $\mathrm{Li}^{1}$ and Zhijun Cao ${ }^{1 *}$ \\ ${ }^{1}$ State Key Laboratory of Animal Nutrition, Beijing Engineering Technology Research Center of Raw Milk Quality and Safety \\ Control, College of Animal Science and Technology, China Agricultural University, Beijing, China, ${ }^{2}$ Department of Animal \\ Science, Faculty of Agriculture, Lorestan University, Khorramabad, Iran
}

\section{OPEN ACCESS}

Edited by:

Joao H. C. Costa University of Kentucky, United States

Reviewed by:

Peter Erickson, University of New Hampshire,

United States

Melissa Cantor,

University of Guelph, Canada

*Correspondence:

Zhijun Cao

caozhijun@cau.edu.cn

Specialty section: This article was submitted to

Animal Nutrition,

a section of the journal

Frontiers in Animal Science

Received: 26 November 2021

Accepted: 27 January 2022

Published: 25 February 2022

Citation:

Alugongo GM, Xiao J, Azarfar A, Liu S, Yousif MH, Ma Y, Wang Y, Li S and Cao Z (2022) Effects of Milk Feeding Strategy and Acidification on Growth Performance, Metabolic Traits,

Oxidative Stress, and Health of Holstein Calves.

Front. Anim. Sci. 3:822707. doi: 10.3389/fanim.2022.822707
Effects of milk feeding strategy and acidification on calf growth, metabolic traits, oxidative stress, and health were evaluated in the first 78 days of life. Holstein calves ( $N=48 ; 12$ calves/treatment) were assigned to 1 of the 4 treatments in a $2 \times 2$ factorial arrangement of milk feeding strategy [6 L/d (MOD) or $12 \mathrm{~L} / \mathrm{d}(\mathrm{HIGH})$ of milk] and acidification [non-acidified milk (NAM) or acidified milk (ACM)] on day 2. Calves were bucket-fed milk as follows: $6 \mathrm{~L} / \mathrm{d}$ from days 2 to 49 for MOD and $6 \mathrm{~L} / \mathrm{d}$ from days 2 to 49, $12 \mathrm{~L} / \mathrm{d}$ from days 7 to 42 , and $8 \mathrm{~L} / \mathrm{d}$ from days 43 to 49 for $\mathrm{HIGH}$ calves. All calves were then fed $4 \mathrm{~L} / \mathrm{d}$ from days 50 to 56 . Starter and water were available ad libitum, while hay was fed at $5 \%$ of starter from day 64. Calves were weighed, measured, and blood (except days 14, 42 and 56) sampled on days 2, 14, 28, 42, 49, 56, 63 and 78. Data were analyzed using Mixed PROC of SAS with time as repeated measurements. Fecal scores, checked daily, were examined by the logistic regression using a binomial distribution in GLIMMIX procedure. There were no three-way interactions observed for all the parameters. We detected a milk feeding strategy $\times$ time interaction for starter intake, body weight, ADG, ADG/ME, FE, structural measurements, and glucose. Although, overall (558.0 vs. 638.6 g/d), HIGH calves tended to consume less starter compared to MOD, significant differences were only observed in week 8. The HIGH calves had greater ADG during days 2-14 (1.12 vs. $0.75 \mathrm{~kg} / \mathrm{d}$ ) and tended to have greater ADG on days 15-28 (0.79 vs. 0.55$)$ and 2942 (0.86 vs. 0.60) and lower on days 57-63 (0.11 vs. 0.38) compared to MOD calves. The HIGH calves had greater BW from days 28 to 78 compared to MOD, while NAM were bigger compared to ACM calves from days 49 to 78 . The HIGH calves had lower overall feed and metabolizable energy efficiencies compared to MOD. Except for BW and heart girth, no milk acidification $\times$ time interaction was observed for starter intake, ADG, FE, or ADG/ME. Blood glucose in calves fed NAM-HIGH and ACM-HIGH were greater compared to those fed moderate milk volumes on day 28 only. Albeit, feeding strategy 
had no effect, calves fed ACM had lower likelihood of experiencing diarrhea (odds ratio = 1.32; 95\% confidence interval: 1.018-1.698) compared to those fed NAM. Overall milk feeding strategy had no effect on growth, while milk acidification reduced growth in calves, despite lowering the likelihood of experiencing diarrhea.

Keywords: calf, high milk volume, acidified milk, weaning, health

\section{INTRODUCTION}

Feeding calves high volumes of milk, at least $20 \%$ of their body weight per day, is recommended in light of empirical evidence for improved calf growth, health, and future productive potential (Khan et al., 2011; Kiezebrink et al., 2015). This amount is contrary to the conventional feeding strategies, where calves are fed a restricted amount $(4 \mathrm{~L} / \mathrm{d})$ of milk or milk replacer $(\mathrm{MR})$ to encourage starter intake before weaning. Alternatively, calves are fed high volumes of milk in the first 4-6 weeks of life followed by a stepdown weaning procedure to encourage starter intake and promote or maintain ADG postweaning (de Passillé et al., 2011; Rosenberger et al., 2017; Dennis et al., 2018). Increased starter intake provides the substrates required for rumen development (Jasper and Weary, 2002), hence mitigating the nutritional deficiency that might arise due to poor digestibility of solid feed and to a greater extent, a less developed reticulorumen (Huber, 1969; Huber et al., 1984). Recent studies have shown that despite early introduction to calf starter, calves fed more than $6 \mathrm{~L} / \mathrm{d}$ consume significantly less starter before weaning process commences (de Passillé and Rushen, 2016; Benetton et al., 2019; Neave et al., 2019). For example, de Passillé and Rushen (2016) reported that calves offered $12 \mathrm{~L} / \mathrm{d}$ of milk took an average of $54 \mathrm{~d}$ to consume at least $200 \mathrm{~g} / \mathrm{d}$ of calf starter for 3 consecutive days. In agreement, calves fed a MR took at least 36 and 47 days to reach 40 and $225 \mathrm{~g}$ of solid feed, respectively (Neave et al., 2019). However, the low starter intake had no effect on growth rates as the extra amount of milk or MR was able to sustain the satiety levels in the preweaning period (Klopp et al., 2019; van Niekerk et al., 2020).

Feeding calves with acidified milk (ACM) is common in some parts of the world (USDA, 2016; Todd et al., 2017; Lorenz et al., 2021) and could be useful when the cost of MR increases (Hill et al., 2013). ACM is prepared by adding organic acids, such as formic acid, to milk as a preservative, so that it can be fed to calves without the need for pasteurization (Anderson, 2008; Todd et al., 2017). The acids lower the growth and survival of pathogenic bacteria in milk fed to dairy calves (Richard et al., 1988; Parker et al., 2016) and can be fed for 1-3 days after preparation (Anderson, 2008). When fed to calves, the ACM could also create an unfavorable environment that hinders pathogen proliferation and reduces pathogen load in the gut, resulting in improved whole animal health (Nocek and Braund, 1986), though modern studies evaluating this effect are limited. Generally, several studies have explored calf physiology, gut microbiology, and behavior relative to feeding ACM or MR (Hill et al., 2013; Todd et al., 2017). Although, some studies reported relatively lower intakes of acidified milk relative to non-acidified milk (NAM), calf performance was not negatively influenced when calves were fed MR (Todd et al., 2017, 2018). Feeding ACM products to calves was common in the 1980s (Bush and Nicholson, 1987). However, it was not until recently that interest in this feeding management has gained momentum in some production systems (Hill et al., 2013), thanks to the need to feed calves high volumes of milk (Overvest et al., 2016), which helps maintain milk or MR quality following acidification by inhibiting the growth of the pathogenic microbiota.

Higher milk production in the future (Soberon et al., 2012; Gelsinger et al., 2016) is a strong incentive for dairy producers to increase the amount of milk they feed dairy calves. Moreover, calf welfare concerns among the public are continuously emerging (Costa et al., 2019), prompting dairy stakeholders to think of more innovative ways to feed and manage calves. Previous research in our laboratory showed that ACM could be used as an alternative to pasteurized milk in feeding calves for the first 21 days of life (Deng et al., 2017; Zou et al., 2017). However, the effects of feeding higher volumes of acidified non-saleable milk on growth and performance before and after weaning have not been fully explored in dairy calves. Hence, more research is required to understand the biochemical and physiological mechanisms through which growth is maintained or even improved with acidified non-saleable whole milk feeding. Thus, we set up an experiment to explore the effects of feeding high volumes of ACM in the preweaning period on the growth and performance of dairy calves. We hypothesized that calves receiving high volumes of ACM would have improved performance compared to those receiving NAM. Therefore, the objective of this study was to investigate the effects of feeding either moderate (MOD) or high (HIGH) volumes of milk with or without acidification and their interactions on the nutrient intake, growth, oxidative stress, and health parameters of dairy calves in the first 78 days of life.

\section{MATERIALS AND METHODS}

\section{Treatments, Animals, and Feeding}

This study was conducted at the Zhongyuan Dairy Farm (Xinle, Hebei, P.R. China) from October 2018 to January 2019. Animal procedures were done according to the procedures outlined under Regulations for the Administration of Affairs Concerning Experimental Animals and the National Committee of Science and Technology of China (14 November 1988). Animal care and use were approved by the Ethical Committee of the College of Animal Science and Technology of China Agricultural University (Yuanmingyuan Road, Haidian District, Beijing; Case number: AW71111202-1-1). The number of animals per treatment was determined by performing a power analysis 
(PROC GLMPOWER, SAS 9.4) to detect an $8.4 \%$ difference in ADG where the mean was $0.59 \mathrm{~kg} / \mathrm{d}$ and SD was 0.10 [data derived from Hill et al. (2013)] at an $\alpha=0.05$ and power $=0.80$. The expected means were $0.59,0.64,0.70$, and 0.75 for NAMMOD, ACM-MOD, NAM-HIGH, and ACM-HIGH. Using these values 32 and 128 calves were required for milk strategy and milk acidification, respectively. However, due to the limitation of funds and animals, we recruited only 48 animals for this trial. The forty-eight Chinese Holstein calves (24 females and 24 males) were separated from their dams immediately after birth. The calves were fed $4 \mathrm{~L}$ within $1 \mathrm{~h}$ of birth and $2 \mathrm{~L} 6 \mathrm{~h}$ later of colostrum. The overall mean concentration of serum protein on day 2 was $6.32 \pm 0.17 \mathrm{ml} / \mathrm{dl}$. The calves were blocked by date of birth ( $2 \pm 1$ day of age), BW (37-43 kg), and sex. The calves were individually housed in hutches and assigned to 1 of the 4 treatments $(\mathrm{N}=48 ; 12$ calves per treatment $)$ in a randomized complete block design with a $2 \times 2$ factorial arrangement of different [6 L/d (MOD) or $12 \mathrm{~L} / \mathrm{d}$ (HIGH) of milk] milk feeding strategy and milk acidification [NAM or ACM]. All calves were offered the same batches of non-saleable (transitional milk from fresh cows and non-saleable milk from antibiotic-treated cows) milk beginning $24 \mathrm{~h}$ after birth that was either pasteurized or acidified. The NAM was pasteurized at $72^{\circ} \mathrm{C}$ for $15 \mathrm{~s}$. The ACM was prepared by diluting non-saleable milk (at a temperature of $<5^{\circ} \mathrm{C}$ ) with diluted $88 \%$ formic acid (for every $1 \mathrm{~L}$ of milk with $30 \mathrm{ml}$ of diluted acid). The formic acid was first mixed with water at the rate of 1 part formic acid $88 \%$ into 9 parts water. The milk was then mixed every $3 \mathrm{~h}$ for 3 times to reduce milk separation (Parker et al., 2016) and used after at least $24 \mathrm{~h}$ of fermentation. The milk was fed at a temperature of $37-39^{\circ} \mathrm{C}$. All calves were fed $6 \mathrm{~L} / \mathrm{d}$ in the first 6 days. Afterward, the MOD calves were supplied with the same amount $(6 \mathrm{~L} / \mathrm{d})$ of milk daily at 08:00 $\mathrm{h}$ and 14:00 h until day 49. The HIGH calves were allowed access to milk for at least $30 \mathrm{~min}$ at $08: 00 \mathrm{~h}, 14: 00 \mathrm{~h}$, and 20:00 h from day 7 to 42 . They were then weaned stepwise, beginning day 42 by reducing the volume fed to $8 \mathrm{~L} / \mathrm{d}$ fed at $08: 00 \mathrm{~h}$ and 14:00 h in equal amounts. From day 50 until complete weaning on day 56, all calves received $4 \mathrm{~L} / \mathrm{d}$ in an equal amount at 08:00 h and 14:00 h. Milk was provided in plastic buckets that were sanitized with an iodine detergent in hot water and inverted in a position to dry after every milk feeding session. Calves were allowed free access to calf starter from day 4 (Sanyuan Feed Co. Ltd., Hebei, China). Oat hay was offered at $5 \%$ of the calf starter fed beginning from day 65 . The hay was mixed with calf starter. Newly fed and refused starter and milk were recorded daily. Water was freely available to the calves. The calves were housed in individual hutches (the inside dimensions of the hutches were $215 \mathrm{~cm}$ long, $120 \mathrm{~cm}$ wide, and $136 \mathrm{~cm}$ high with an outside iron bar fenced area of $160 \mathrm{~cm}$ long, $120 \mathrm{~cm}$ wide, and $110 \mathrm{~cm}$ high) on a sand bedding that was layered with sawdust when the temperature dropped below $0^{\circ} \mathrm{C}$. All calves were weaned on day 56 and remained in the hutches until day 78 .

\section{Data and Sample Collection}

Milk and Feed Sampling and Analysis

Milk fed to the calves was sampled biweekly and analyzed for protein, fat, lactose, and solid non-fat on the farm
TABLE 1 | Chemical composition of pasteurized and acidified milk.

\begin{tabular}{|c|c|c|}
\hline \multirow[t]{2}{*}{ Composition (\%) } & \multicolumn{2}{|c|}{ Milk $^{a}$} \\
\hline & Pasteurized & Acidified \\
\hline Fat & 4.11 & 3.82 \\
\hline Protein & 3.58 & 3.55 \\
\hline Lactose & 5.35 & 5.34 \\
\hline $\mathrm{SNF}^{\mathrm{b}}$ & 9.66 & 9.61 \\
\hline $\mathrm{ME}^{\mathrm{c}}(\mathrm{Mcal} / \mathrm{L}$ as fed $)$ & 0.74 & 0.72 \\
\hline
\end{tabular}

a Milk sampled bi-weekly at feeding, tested by a spectrophotometer (Ultramilker UL4OAC, Ultrasun Technologies Co., Ltd., Hangzhou, China).

${ }^{b} \mathrm{SNF}$, solids non-fat.

${ }^{c} M E$ of milk estimated as follows: $M E=0.93[(0.0923 \times$ fat\% $)+(0.0492 \times S N F \%)-$ 0.0564] (Drackley, 2008).

TABLE 2 | Chemical composition of calf starter (CS) and oat hay $(\mathrm{OH})$ on a DM basis.

\begin{tabular}{|c|c|c|}
\hline Nutrient $^{\mathrm{a}}$ & Calf starter ${ }^{b}$ & Oat hay \\
\hline DM, \% as fed & 89.4 & 93.2 \\
\hline $\mathrm{CP}$ & 22.4 & 6.18 \\
\hline Fat & 3.65 & 2.75 \\
\hline TDN & 82.0 & - \\
\hline Starch & 30.1 & - \\
\hline NFC & 41.7 & - \\
\hline NDF & 13.5 & 44.1 \\
\hline ADF & 7.11 & 33.7 \\
\hline Ash & 8.05 & 4.48 \\
\hline $\mathrm{ME}^{\mathrm{c}, \mathrm{d}}(\mathrm{Mcal} / \mathrm{kg})$ & 2.93 & 2.15 \\
\hline
\end{tabular}

a Percent of DM, unless otherwise stated; analyzed by NIRSTM DS2500 FOSS.

${ }^{b}$ Concentrate starter (Sanyuan Feed Co. Ltd., Hebei, P. R. China). Contained 12.8\% corn, 19.8\% soybean meal, $10.1 \%$ wheat bran, $8.3 \%$ extruded soybean, $40.0 \%$ steam-flaked corn, $3.0 \%$ canola meal, $2.0 \%$ cottonseed meal and $4.0 \%$ premix compounds.

${ }^{C} M E=$ Calculated ME for calf starter according to NRC (2001) equations.

${ }^{d} \mathrm{ME}=0.239006 \times 9.0 \mathrm{MJ} / \mathrm{kg} \mathrm{DM}$; estimated based on oat hay composition by Du et al. (2019).

laboratory (Ultramilker UL40AC, Ultrasun Technologies Co., Ltd, Hangzhou, China). Representative feed samples were collected and stored in an air-sealed nylon bags until further analyses. Dry matter, CP, NDF, ADF, ether extract, and ash were analyzed by NIRSTM DS2500 FOSS. Tables $\mathbf{1 ,} 2$ contain the nutritional composition of milk, starter, and oat hay used.

\section{Body Weight and Structural Measurements}

Calves were weighed by a digital scale on days 2 (the day of enrollment in the trial), 14, 28, 42, 49, 56, 63, and 78. On the same days, body structural measurements including body length (distance between the points of shoulder and point of pin bone), heart girth (circumference of the chest measured directly behind the front leg), withers height (distance from the base of the front feet to the withers), and hip height (distance from the base of the rear feet to hook bones) measurements were recorded. 


\section{Blood Collection and Analysis}

Blood was sampled from the jugular vein in evacuated tubes containing no anticoagulant for serum separation and with $\mathrm{K}_{2}$ EDTA for plasma on days 2 (to confirm passive transfer of immunity only), 28, 49, 63, and 78 for determining concentrations of glucose, NEFA, total protein (TP), plasma urea nitrogen (PUN), insulin, insulin-like growth factor 1 (IGF-1), cholecystokinin (CCK), and oxidative biomarkers. The blood was subsequently centrifuged at $3,500 \times g$ for $15 \mathrm{~min}$ at $10^{\circ} \mathrm{C}$ to separate plasma and serum. The blood samples were then stored at $-20^{\circ} \mathrm{C}$ until further analysis. Serum total protein and glucose were determined using a handheld optical refractometer and glucometer, respectively, as reported elsewhere (Alugongo et al., 2017; Xiao et al., 2018). Concentrations of NEFA, PUN, IGF-1, and oxidative biomarkers [glutathione peroxidase (GSH$\mathrm{Px}$ ), superoxide dismutase (SOD), malondialdehyde (MDA), and the total antioxidant capacity (TAOC)] were determined using the hydroxylamine, xanthine oxidase reaction, thiobarbituric acid, and calorimetry methods, respectively, according to kit manufacturer's instructions [Jiancheng Bioengineering Institute, Nanjing, China; Alugongo et al. (2017)]. Plasma insulin concentration was measured by RIA (Steinhoff-Wagner et al., 2011). An ELISA methodology was used to analyze the CCK. Concentrations of NEFA, PUN, IGF-1, GSH-Px, SOD, MDA, and TAOC were quantified by an automated biochemistry analyzer (Model GF-D200, Caihong Co., Ltd., Shandong, China). Insulin was measured by a multitube radioimmunoassay counter (Model Bfm-96, Zhongcheng Electromechanical Technology Co., Ltd., Hefei, China), whereas IGF-1 and CCK by enzyme-immunoassay instrument (Thermo Multiskan Ascent, Franklin, USA).

\section{Fecal Scoring}

Fecal scores were recorded daily for individual calves by a trained team member based on a scale of 1-4 (Magalhães et al., 2008). Fecal consistency was scored as 1 when firm, 2 when soft or moderate consistency, 3 when runny or mild diarrhea, and 4 when watery and profuse diarrhea. A calf was considered diarrheic if it had a fecal score of $>2$. Calves that had a fever with temperatures $\geq 39.5^{\circ} \mathrm{C}$, inappetence, droopy ears, nasal discharge, and labored breathing were treated with antibiotics by the farm veterinarian. Electrolytes were administered intravenously through the jugular vein to visually dehydrated calves.

\section{Statistical Analysis}

Data for feed (milk, starter, hay, and metabolizable energy) intake were summarized by week. The ADG was calculated as the differences in BW between 2 consecutive sampling days (days $2,14,28,42,49,56,63$, and 78 ) divided by the number of days in that period, and the data was also used to calculate the ADG/ME and feed efficiency in the 7 respective periods. Before analyses, all data were screened for normality using the UNIVARIATE procedure of SAS. The data were analyzed using the MIXED procedure of SAS (SAS 9.4, SAS Institute Inc., Cary, NC) with time (week/period) as a repeated measure for dependent variables (starter intake, BW, ADG, ADG/ME, feed efficiency, structural measurements, blood metabolites, and oxidative biomarkers).
The model included fixed effects of milk feeding strategy, milk acidification, time, and the interaction terms for milk feeding strategy $\times$ milk acidification, milk feeding strategy $\times$ time, and milk acidification $\times$ time. Three variance-covariance structures (simple, auto-regressive type 1 , and compound symmetry) were tested and the covariance structure with the lowest Akaike and information criterion was used. The sex effect was excluded from the final model after it was tested and found to be insignificant. The calf was the subject of the repeated statement. The least-square means were separated by the PDIFF statement, and the Tukey-Kramer adjustment was applied to account for the multiple comparisons. The slice option was used to determine which groups were different when a 3-way interaction was significant. The effect of experimental treatments on the likelihood of experiencing diarrhea was examined by the logistic regression using a binomial distribution in GLIMMIX procedure of SAS version 9.4. Significance was declared at $P<0.05$ and a trend was declared at $0.05 \leq P<0.10$. The individual calf was the experimental unit.

\section{RESULTS}

\section{Effect of Milk Feeding Strategy and Milk Acidification on Milk, Starter, and Hay Intake}

As planned, calves on HIGH volumes consumed more milk than those fed MOD volumes of milk ( $P<0.001$; Table 3$)$. The acidification of milk had no effect on the milk intake within MOD, but lowered intake in the HIGH treatments. Similar trends were observed for milk DM, milk protein, and milk fat intakes. Although starter intake tended (MOD $=638.6$ vs. $\mathrm{HIGH}=558.0$ $\mathrm{g} / \mathrm{d} ; P=0.07)$ to be affected by the milk feeding strategy, a milk feeding strategy by week interaction showed that calves fed HIGH compared to MOD only ate less starter at week 8 of age $(P=$ 0.01 ; Figure 1). Milk acidification had no effect on the starter intake. Hay intake, fed only between days 65 and 78, was similar between treatments (hay $=111.4 \mathrm{~g} / \mathrm{d}$ ). The differences in milk volumes and starter intakes resulted in variation in overall $\mathrm{ME}$ intake such that NAM-HIGH $>$ ACM-HIGH $>$ NAM-MOD > ACM-MOD (Table 3). This was specifically contributed to by differential intakes in ME among the treatments between weeks 2 and 7 of the trial. The ME intakes were not different between treatments from week 8 to the end of the study.

\section{Effect of Milk Feeding Strategy and Milk Acidification on BW, ADG, and Feed Efficiency}

The results for BW, ADG, and FE are presented in Table 3. The initial birth weight was similar among groups, with a mean of $40.9 \pm 1.83 \mathrm{~kg}$. By weaning on day 56 , the BW was in the following order: NAM-HIGH > ACM-HIGH > NAM-MOD > ACM-MOD. However, by the end of the study, NAM-HIGH had the greatest BW, NAM-MOD and ACM-HIGH were similar, and ACM-MOD had the least. We detected a milk feeding strategy $\times$ week interaction for overall BW and ADG $(P<0.001$; Figure 2). Calves on HIGH treatment exhibited a greater ADG during days 
TABLE 3 | Least square means for the effect of milk feeding strategy and milk acidification on starter, hay (offered from day 64 to 78 ) and metabolizable energy intake for calves fed 6 (MOD) or $12 \mathrm{~L}(\mathrm{HIGH})$ of milk with (ACM) or without (NAM) acid.

\begin{tabular}{|c|c|c|c|c|c|c|c|c|c|c|c|c|}
\hline \multirow[t]{2}{*}{ Item } & \multicolumn{2}{|c|}{ NAM } & \multicolumn{2}{|c|}{$\mathrm{ACM}$} & \multirow[t]{2}{*}{ SEM } & \multicolumn{7}{|c|}{$P$-value ${ }^{a}$} \\
\hline & MOD & HIGH & MOD & HIGH & & Strategy & ACID & INT & Time & $1^{b}$ & $2^{\mathrm{b}}$ & $3^{b}$ \\
\hline \multicolumn{13}{|l|}{ Milk intake ${ }^{c}, g / d$} \\
\hline DM & 789.4 & $1,246.0$ & 764.8 & $1,171.1$ & 9.21 & $<0.001$ & $<0.001$ & 0.01 & $<0.0001$ & $<0.001$ & 0.001 & 0.005 \\
\hline Protein & 205.7 & 324.6 & 202.5 & 310.0 & 2.43 & $<0.001$ & $<0.001$ & 0.02 & $<0.0001$ & $<0.001$ & 0.005 & 0.01 \\
\hline Fat & 236.1 & 372.7 & 217.3 & 332.7 & 2.66 & $<0.001$ & $<0.001$ & $<0.001$ & $<0.0001$ & $<0.001$ & $<0.001$ & $<0.001$ \\
\hline Milk intake, L/d & 5.75 & 9.07 & 5.70 & 8.73 & 0.07 & $<0.001$ & 0.01 & 0.04 & $<0.0001$ & $<0.001$ & 0.01 & 0.02 \\
\hline Starter Intake, g/d & 678.1 & 559.3 & 599.1 & 556.7 & 43.6 & 0.07 & 0.35 & 0.38 & $<0.0001$ & $<0.001$ & 0.19 & 0.18 \\
\hline Hay intake ${ }^{d}, g / d$ & 118.4 & 107.2 & 111.7 & 108.3 & 4.77 & 0.13 & 0.56 & 0.42 & $<0.0001$ & 0.70 & 0.63 & 0.58 \\
\hline ME intake ${ }^{e}, \mathrm{Mcal} / \mathrm{d}$ & 4.91 & 6.52 & 4.58 & 6.14 & 0.12 & $<0.001$ & 0.01 & 0.84 & $<0.0001$ & $<0.001$ & 0.01 & $<0.001$ \\
\hline \multicolumn{13}{|l|}{ BW $^{f}, \mathbf{k g}$} \\
\hline Initial & 40.7 & 41.5 & 40.6 & 40.8 & 1.52 & 0.74 & 0.80 & 0.98 & - & - & - & - \\
\hline Weaning & 75.7 & 86.8 & 70.9 & 78.3 & 1.52 & $<0.001$ & $<0.001$ & $<0.001$ & - & - & - & - \\
\hline Final & 96.7 & 102.5 & 90.7 & 96.4 & 1.52 & $<0.001$ & $<0.001$ & 0.001 & - & - & - & - \\
\hline Overall & 67.2 & 76.0 & 64.6 & 70.2 & 1.20 & $<0.001$ & 0.001 & 0.19 & $<0.001$ & $<0.001$ & $<0.001$ & 0.25 \\
\hline $\mathrm{ADG}^{\mathrm{g}}, \mathrm{kg} / \mathrm{d}$ & 0.71 & 0.72 & 0.60 & 0.65 & 0.03 & 0.38 & 0.01 & 0.55 & $<0.001$ & $<0.001$ & 0.08 & 0.19 \\
\hline ADG/ME, kg/Mcal & 0.14 & 0.10 & 0.12 & 0.09 & 0.01 & $<0.001$ & 0.02 & 0.37 & $<0.0001$ & $<0.001$ & 0.09 & 0.66 \\
\hline $\mathrm{FE} E^{\mathrm{h}}, \mathrm{kg} / \mathrm{kg}$ & 0.64 & 0.55 & 0.63 & 0.52 & 0.02 & 0.01 & 0.50 & 0.86 & $<0.001$ & $<0.001$ & 0.43 & 0.48 \\
\hline
\end{tabular}

a Probability of a significant effect of milk feeding strategy (Strategy), milk acidification (ACID) or interaction of milk feeding strategy and milk acidification (INT); Time = week or period. ${ }^{b}$ Interactions: Strategy $\times$ Time $=$ milk feeding strategy $\times$ Time, $A C I D \times$ Time $=$ milk acidification $\times$ Time, and Strategy $\times$ ACID $\times$ Time $=$ milk feeding strategy $\times$ milk acidification $\times$ Time, respectively.

${ }^{c}$ Milk intake: days 4 to 56.

${ }^{d}$ Hay intake, hay was fed from day 65 to the end of the study.

${ }^{\mathrm{e}} \mathrm{ME}$ intake, total metabolizable energy in milk, calf starter and hay.

${ }^{f} B W$, body weight.

${ }^{g} A D G$, average daily gain.

${ }^{h} F E$, feed efficiency, calculated as total feed intake (milk, calf starter and hay) divided by average daily gain.

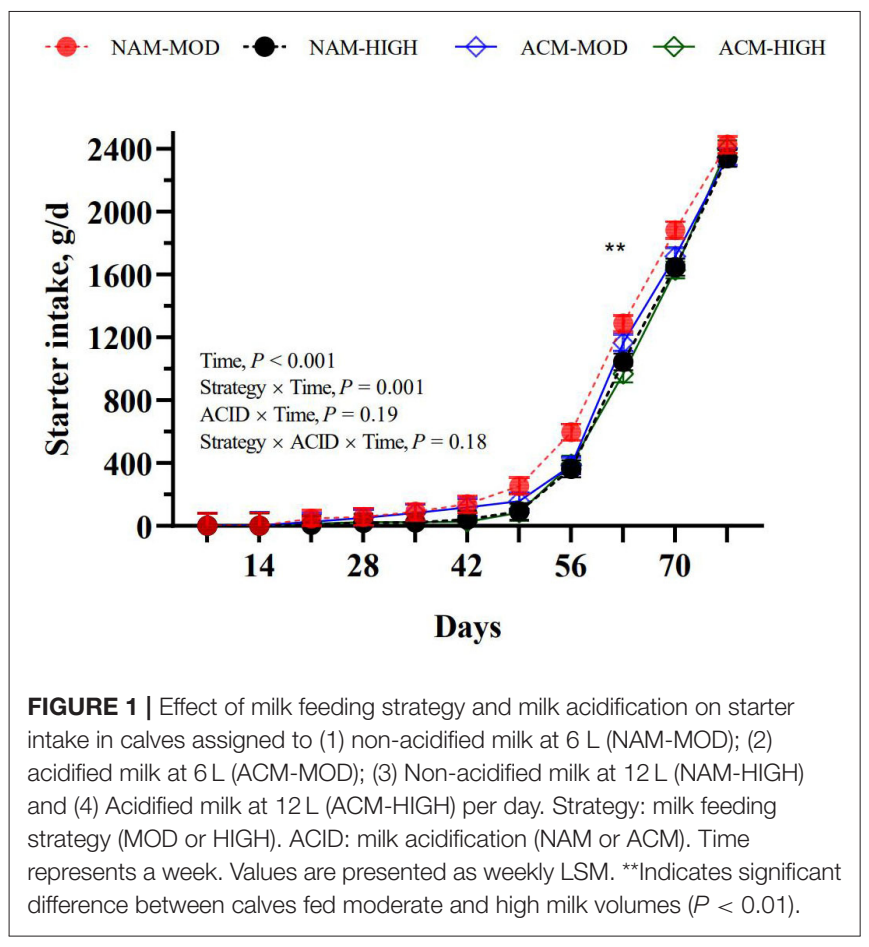

2-14 $(P<0.001)$ and a trend on days $15-28(P=0.10)$ and on days 29-42 $(P=0.05)$ compared to MOD. Between days 42 and 63, HIGH calves experienced a decrease in ADG such that a week after weaning completely from milk the calves grew at a 3 times lower rate compared to MOD calves (MOD $=376$ vs. $\mathrm{HIGH}=109 \mathrm{~g} / \mathrm{d} ; P=0.06$ ). Calves had similar growth rates thereafter. Generally, calves fed HIGH milk volumes had greater BW beginning on day 14 till the end of the study on day 78 . An ACID $\times$ time interaction was also observed for BW $(P<$ 0.001 ), whereby, calves were consistently similar in BW until day 42. Thereafter, calves fed ACM tended to decrease in BW ( $\mathrm{d} 49$; $P=0.07)$ and significant differences were observed from days 56 to $78(P<0.01)$. Although we did not observe differences in ADG for a specific time period, a trend for ACID $\times$ time interaction was also observed $(P=0.08)$ with overall greater ADG in calves fed NAM compared to ACM milk $(P=0.01)$. We observed a milk feeding strategy $\times$ time interactions $(P<$ 0.001 ) for feed and ME efficiency, where calves on HIGH milk volumes had lower overall feed and ME efficiency compared to MOD $(P<0.05)$. Calves fed high volumes of milk had significantly low $\mathrm{FE}$ between days 43 and $49(\mathrm{MOD}=0.72$ vs. $\mathrm{HIGH}=0.40 ; P<0.001)$. Calves fed high volumes of milk had significantly low ADG/ME between days 43 to 49 and days 57 to $63(P<0.001)$. ACM had no effect on overall FE and 
ADG/ME, but tended to affect their interactions with time ( $P$ $<0.10)$. There were no three-way interactions between milk feeding strategy, ACID, and period for overall BW, ADG, FE, and ADG/ME.

\section{Effect of Milk Feeding Strategy and Milk Acidification on Structural Measurements}

Structural measurements are shown in Table 4. Interactions of milk feeding strategy $\times$ day were observed for height $(P=$ $0.02)$, length $(P=0.02)$, abdominal girth $(P<0.001)$, and heart girth $(P=0.10)$. Calves fed high volumes of milk had greater body length [day $28(\mathrm{MOD}=76.5 \mathrm{vs} . \mathrm{HIGH}=80.0 \mathrm{~cm}$; $0.0003)$, day $42(\mathrm{MOD}=81.1$ vs. $\mathrm{HIGH}=84.3 \mathrm{~cm} ; 0.002)$ and day $49(\mathrm{MOD}=83.9$ vs. HIGH $=86.8 \mathrm{~cm} ; 0.008)]$, heart girth [day $28(\mathrm{MOD}=87.5 \mathrm{vs}$. $\mathrm{HIGH}=91.1 \mathrm{~cm} ; 0.002)$, day $42(\mathrm{MOD}=92.7$ vs. $\mathrm{HIGH}=96.5 \mathrm{~cm} ; 0.001)$, and day 49 $(\mathrm{MOD}=93.9$ vs. $\mathrm{HIGH}=97.4 \mathrm{~cm} ; 0.003)]$, and abdominal girth [day $14(\mathrm{MOD}=88.3$ vs. $\mathrm{HIGH}=92.9 \mathrm{~cm} ; 0.03)$, day 28 (MOD $=90.4$ vs. $\mathrm{HIGH}=96.2 \mathrm{~cm} ; 0.001)$, day 42 $(\mathrm{MOD}=94.9$ vs. $\mathrm{HIGH}=102.9 \mathrm{~cm} ;<0.0001)$, and day 49 $(\mathrm{MOD}=95.9$ vs. $\mathrm{HIGH}=100.3 \mathrm{~cm} ; 0.06)]$ mainly before weaning $(P<0.05)$. Feeding ACM resulted in an ACID $\times$ day interaction for heart girth $(P=0.001)$ and abdominal girth $(P$ $=0.06)$. There were no specific differences at individual days except for heart girth on day 78 (NAM = 104.4 vs. ACM = $100.4 \mathrm{~cm} ; P<0.001)$. There were no three-way interactions between milk feeding strategy, ACID, and period for overall structural measurements.

\section{Effect of Milk Feeding Strategy and Milk Acidification on Blood Metabolites}

Various blood metabolites related to energy and protein metabolism were measured in this experiment (Table 5). No three-way milk feeding strategy $\times$ ACID $\times$ day interactions were observed for all the blood parameters except for a trend in glucose $(P=0.09)$ concentration. Blood glucose in calves fed NAM-HIGH and ACM-HIGH were greater compared to those fed moderate milk volumes on d 28 only. Interactions between milk feeding strategy and day were observed for TP $(P=0.03)$ and PUN (trend; $P=0.07$ ). On day 78, HIGH fed calves tended to have greater plasma concentration of TP compared to MOD $(\mathrm{MOD}=5.57$ vs. $\mathrm{HIGH}=5.91 \mathrm{~g} / \mathrm{dl}$; $P=0.11)$. Calves fed ACM had lower PUN compared to those fed NAM on day 28 (NAM $=4.55$ vs. $\mathrm{ACM}=3.54$ $\mathrm{mmol} / \mathrm{L} ; P=0.01)$. No differences were observed on the other days. Neither milk feeding strategy, milk acidification nor their interactions had an effect on the NEFA concentration. Overall, milk feeding strategy $(P=0.003)$ and milk acidification $(P=$ 0.03 ) independently affected insulin concentration. Both IGF-1 and CCK were neither affected by milk feeding strategy nor by milk acidification.

\section{Effect of Milk Feeding Strategy and Milk Acidification on Oxidative Biomarkers}

The oxidative biomarkers tested in this experiment included GSH-Px, SOD, MDA, and TAOC (Table 6). No interactions between milk feeding strategy or milk acidification and time were observed for the oxidative biomarkers. Similarly, treatment had no effect on these biomarkers, except for TAOC. Overall, milk acidification reduced the concentration of TAOC $(P=0.01)$.

\section{Effect of Milk Feeding Strategy and Milk Acidification on the Likelihood of Experiencing Diarrhea}

Table 7 reports the logistic models for the likelihood of experiencing diarrhea (fecal score $>2$ ) during the preweaning period. Calves fed moderate volumes of milk had a similar chance of having diarrhea compared to those fed high volumes of milk. On the other hand, calves fed NAM had higher chances of experiencing diarrhea compared to calves fed ACM (odds ratio $=1.32 ; 95 \%$ confidence interval: $1.018-1.698 ; P=0.04)$.

\section{DISCUSSION}

Calves readily drink ACM when they are introduced to it early in life (Anderson, 2008). In the milk feeding period, calves fed $6 \mathrm{~L}$ of milk consumed almost all the milk offered, with the ACM group consuming slightly less. Milk intakes in the calves assigned to $12 \mathrm{~L} / \mathrm{d}$ were significantly lower in calves fed ACM compared to NAM. However, they were not as low as a study conducted in Canada, in which calves fed ad libitum milk treated with either formic, formaldehyde, or propionic acids consumed significantly lesser amounts of milk compared to the non-acidified regime (Bush and Nicholson, 1987). In fact, the formic acid (0.1\%, v/v of $85 \%$, wt $/ \mathrm{vol}$ ) treated calves consumed (130.9 vs. $268.1 \mathrm{~kg}$ ) almost a half the amount consumed by the non-acidified calves from birth to day 28 of life in that study. In a more recent study, calves consumed around $1.41 \mathrm{~kg} / \mathrm{d}$ DM $(\sim 9.4 \mathrm{~L} / \mathrm{d})$ of acidified MR offered (Overvest et al., 2016). The differences in intakes across studies can be ascribed to factors such as temperature of the milk as well as the frequency of feeding and palatability among individual calves (Todd et al., 2018). While we fed milk at $37^{\circ} \mathrm{C}$, Bush and Nicholson (1987) fed their calves at an ambient temperature of $15-20^{\circ} \mathrm{C}$, while Todd et al. (2018) did not indicate the MR feeding temperature, rather they indicated that the milk was stored under ambient temperature during the winter months. The ACM intakes in our study were also higher than what has been reported elsewhere in calves fed NAM twice daily for at least 30 min each time (Moallem et al., 2010).

Increasing starter intake before weaning is desirable in dairy calves. As per the experimental design, calves fed higher volumes of milk consumed less starter compared to the moderate level preweaning. Studies conducted by our research group in which calves drank more than $8 \mathrm{~L} / \mathrm{d}$ at peak showed that starter intake during the preweaning period was relatively low (Alugongo et al., 2017; Xiao et al., 2018) ranging from 103.8 to $313.5 \mathrm{~g} / \mathrm{d}$ on average in calves fed calf starter only from day 4 . Starter intake increased sharply during weaning, resulting in calves consuming greater amounts of starter during the week before and a week after weaning, in agreement with other studies (Jasper and Weary, 2002; Benetton et al., 2019). The increase in starter intake was marked in the calves offered less amount of milk, 

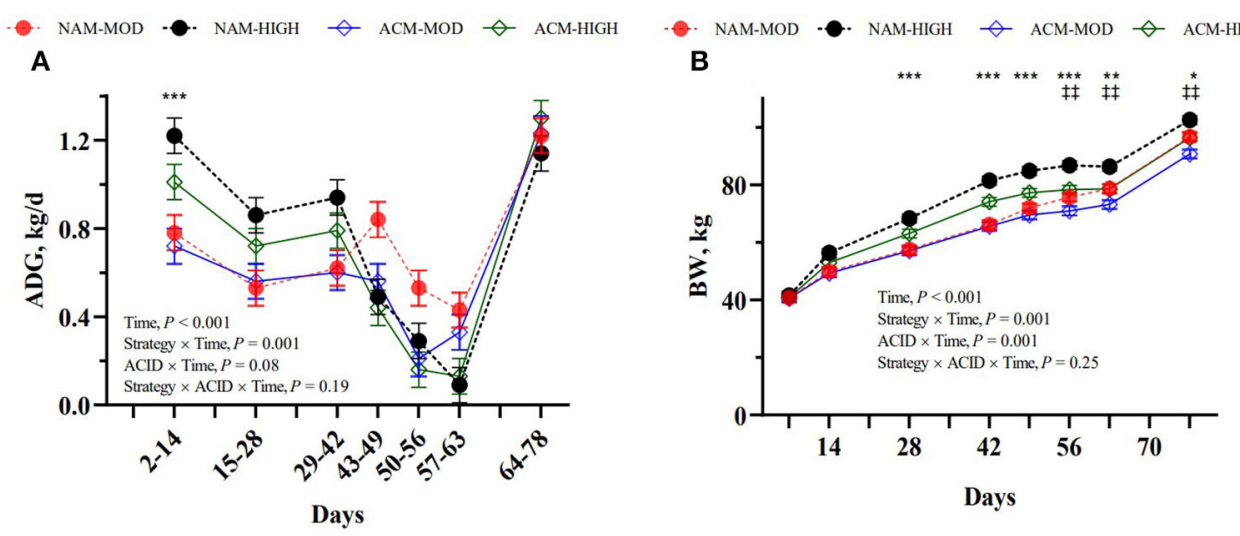

FIGURE 2 | Effect of milk feeding strategy and milk acidification on ADG (A) and body weight (B) in calves assigned to (1) non-acidified milk at $6 \mathrm{~L}$ (NAM-MOD); (2) acidified milk at $6 \mathrm{~L}$ (ACM-MOD); (3) non-acidified milk at $12 \mathrm{~L}$ (NAM-HIGH) and (4) acidified milk at $12 \mathrm{~L}$ (ACM-HIGH) per day. Strategy: milk feeding strategy (MOD or HIGH). ACID: milk acidification (NAM or ACM). Time for ADG represents the difference in BW between two consecutive days on which BW was measured divided by the number of days in that period. Values are presented as weekly LSM; *Indicates moderate vs. high volume of milk fed $\left.{ }^{*} P<0.05 ;{ }^{* \star}<0.01 ;{ }^{* \star *}<0.001\right) ;{ }^{*}$ indicates non-acidified vs. acidified milk ( $P<0.05 ; ~ ¥ \neq<0.01)$.

TABLE 4 | Least square means for effect of milk feeding strategy and milk acidification on body structural measurements for calves fed 6 (MOD) or 12 L (HIGH) of milk with (ACM) or without (NAM) acid.

\begin{tabular}{|c|c|c|c|c|c|c|c|c|c|c|c|c|}
\hline Item $^{\mathrm{a}}$ & \multicolumn{2}{|c|}{ NAM } & \multicolumn{2}{|c|}{$\mathrm{ACM}$} & SEM & \multicolumn{7}{|c|}{$P$-value ${ }^{b}$} \\
\hline Length, cm & 80.7 & 83.4 & 80.4 & 81.8 & 0.45 & $<0.001$ & 0.04 & 0.14 & $<0.001$ & 0.001 & 0.33 & 0.59 \\
\hline Heart girth, cm & 91.6 & 95.5 & 91.0 & 92.5 & 0.55 & $<0.0001$ & 0.003 & 0.04 & $<0.001$ & 0.10 & 0.001 & 0.43 \\
\hline Abdominal girth, $\mathrm{cm}$ & 96.7 & 101.5 & 95.5 & 98.3 & 0.88 & $<0.001$ & 0.02 & 0.27 & $<0.001$ & $<0.001$ & 0.06 & 0.74 \\
\hline
\end{tabular}

altem: Structural measurements taken on $d 2,24,28,49,56,63$ and 78.

${ }^{b}$ Probability of a significant effect of milk feeding strategy (Strategy), milk acidification (ACID) or interaction of milk feeding strategy and milk acidification (INT); Time = day.

${ }^{c}$ Interactions: Strategy $\times$ Time $=$ milk feeding strategy $\times$ Time, ACID $\times$ Time $=$ milk acidification $\times$ Time, and Strategy $\times$ ACID $\times$ Time $=$ milk feeding strategy $\times$ milk acidification $\times$ Time, respectively.

TABLE 5 | Least square means for the effect of milk feeding strategy and milk acidification on blood metabolites for calves fed 6 (MOD) or 12 L (HIGH) of milk with (ACM) or without (NAM) acid.

\begin{tabular}{|c|c|c|c|c|c|c|c|c|c|c|c|c|}
\hline Item $^{a}$ & \multicolumn{2}{|c|}{ NAM } & \multicolumn{2}{|c|}{$\mathrm{ACM}$} & SEM & \multicolumn{7}{|c|}{$P$-value ${ }^{b}$} \\
\hline $\mathrm{NEFA}, \mu \mathrm{mol} / \mathrm{L}$ & 77.7 & 82.5 & 71.2 & 69.6 & 6.16 & 0.80 & 0.12 & 0.61 & 0.04 & 0.55 & 0.18 & 0.88 \\
\hline TP, g/dl & 5.95 & 5.78 & 5.58 & 5.58 & 0.13 & 0.25 & 0.32 & 0.66 & $<0.0001$ & 0.03 & 0.02 & 0.84 \\
\hline PUN, mmol/L & 4.78 & 4.75 & 4.45 & 4.21 & 0.16 & 0.40 & 0.01 & 0.54 & $<0.0001$ & 0.07 & 0.05 & 0.24 \\
\hline IGF-1, ng/ml & 171.3 & 174.1 & 169.3 & 171.2 & 11.5 & 0.84 & 0.82 & 0.97 & $<0.001$ & 0.94 & 0.97 & 0.99 \\
\hline $\mathrm{CCK}^{\mathrm{d}}, \mathrm{ng} / \mathrm{L}$ & 363.3 & 363.8 & 359.4 & 347.4 & 12.0 & 0.63 & 0.40 & 0.61 & 0.03 & 0.85 & 0.35 & 0.74 \\
\hline
\end{tabular}

altem: Blood sampled on d 28, 49, 63 and 78.

${ }^{b}$ Probability of a significant effect of milk feeding strategy (Strategy), milk acidification (ACID) or interaction of milk feeding strategy and milk acidification (INT); Time = day.

${ }^{c}$ Interactions: Strategy $\times$ Time $=$ milk feeding strategy $\times$ Time, ACID $\times$ Time $=$ milk acidification $\times$ Time, and Strategy $\times$ ACID $\times$ Time $=$ milk feeding strategy $\times$ milk acidification $\times$ Time, respectively.

${ }^{d}$ CCK, cholecystokinin.

which agrees with the findings of Benetton et al. (2019) and could be attributed to greater hunger in these calves. Previous studies on the effect of feeding ACM or MR on starter intake in calves are inconsistent (Hill et al., 2013; Todd et al., 2016). In calves fed at different volumes of milk and milk $\mathrm{pH}$, Hill et al. (2013) reported no differences in starter intake across the 


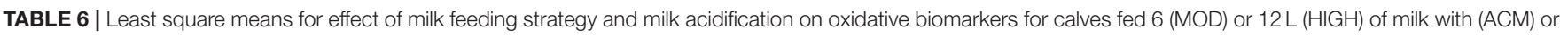
without (NAM) acid.

\begin{tabular}{|c|c|c|c|c|c|c|c|c|c|c|c|c|}
\hline \multirow[t]{2}{*}{ Item $^{a}$} & \multicolumn{2}{|c|}{ NAM } & \multicolumn{2}{|c|}{$\mathrm{ACM}$} & \multirow[t]{2}{*}{ SEM } & \multicolumn{7}{|c|}{$P$-value ${ }^{b}$} \\
\hline & MOD & HIGH & MOD & HIGH & & Strategy & ACID & INT & Time & $1^{c}$ & $2^{c}$ & $3^{c}$ \\
\hline $\mathrm{GSH}-\mathrm{Px}, \mu \mathrm{mol} / \mathrm{ml}$ & 444.4 & 444.0 & 460.2 & 487.2 & 26.5 & 0.62 & 0.27 & 0.61 & $<0.0001$ & 0.51 & 0.39 & 0.50 \\
\hline $\mathrm{SOD}, \mathrm{U} / \mathrm{ml}$ & 33.2 & 32.4 & 28.6 & 31.7 & 2.18 & 0.61 & 0.23 & 0.38 & 0.56 & 0.18 & 0.95 & 0.75 \\
\hline MDA, nmol/L & 2.77 & 2.79 & 2.82 & 2.79 & 0.03 & 0.97 & 0.51 & 0.47 & $<0.001$ & 0.22 & 0.44 & 0.23 \\
\hline TAOC, U/ml & 4.72 & 4.93 & 4.40 & 4.54 & 0.12 & 0.16 & 0.01 & 0.82 & $<0.001$ & 0.33 & 0.92 & 0.90 \\
\hline
\end{tabular}

a Probability of a significant effect of milk feeding strategy (Strategy), milk acidification (ACID) or interaction of milk feeding strategy and milk acidification (INT); Time = day. ${ }^{b}$ GSH-Px, glutathione peroxidase; SOD, superoxide dismutase; MDA, malondialdehyde; TAOC, total antioxidant capacity; Blood sampled on d $28,49,63$ and 78.

${ }^{c}$ Interactions: Strategy $\times$ Time $=$ milk feeding strategy $\times$ Time, $A C I D \times$ Time $=$ milk acidification $\times$ Time, and Strategy $\times$ ACID $\times$ Time $=$ milk feeding strategy $\times$ milk acidification $\times$ Time, respectively.

different treatments studied. Conversely, although mean starter intake was not different in the preweaning period, the onset of its intake, defined as a calf voluntarily consuming at least $100 \mathrm{~g} / \mathrm{d}$ for 2 days consecutively, began on day 32 for acidified compared to day 39.5 for nonacidified MR (Todd et al., 2016). ACM feeding neither decreased nor triggered an increase in starter intake in the preweaning or during the weaning transition period in our study. A week postweaning, calves were eating between 966.9 and $1287.6 \mathrm{~g} / \mathrm{d}$ of calf starter on average. This amount was still low compared to industry standards, where calves weaned at $\sim 8$ week of age are expected to be consuming $1.8-2.4 \mathrm{~kg} / \mathrm{d}$ of starter for 3 consecutive days at the time of weaning (DCHA, 2016). The level of milk fed combined with the relatively abrupt weaning strategy might have caused the failure of our calves to meet the industry standards before they were completely weaned off milk, which agrees with the findings of Roth et al. (2009). Even with a 1week prior decrease in milk volume fed compared to MOD calves and a two-stepdown weaning protocol, starter intake was not stimulated in the HIGH calves. This further highlights the need to increase the number of weaning steps to help calves smoothly transition from milk to starter. Furthermore, recent studies have shown that the cumulative calf starter intake in calves is more critical than the average daily intake at weaning (Quigley et al., 2019). Calf starter contains the non-fiber carbohydrates that are necessary for the development of the gastrointestinal tract. Either increasing the age at weaning or the duration of the weaning period could have boosted starter intake in calves, especially those receiving high milk volumes around the weaning period (de Passillé et al., 2011; Mirzaei et al., 2018). In the light of our results, increasing the number of stepdown steps in the stepdown weaning protocol is recommended for calves to encourage starter intake. Postweaning starter intake between the HIGH and MOD calves were similar, consistent with other studies that have compared feeding low and high volumes of milk to calves (Eckert et al., 2015; Mirzaei et al., 2018). No differences were observed in oat hay intake, probably as a result of feeding at a rate of $\sim 5 \%$ of the starter fed, which was not significantly different during the same period. Calves sorted for and consumed all the hay provided, indicating that the amount offered was not sufficient (Engelking et al., 2020). Limited studies have tried to quantify the amount of oat hay calves can consume pre- and postweaning (Castells et al., 2012, 2013). In the study by Castells et al. (2013),
TABLE 7 | Logistic models for the likelihood of experiencing diarrhea (Fecal score $>2^{\text {a }}$ ) during preweaning (day 2-56) for calves fed moderate (6 L) or high (12 L) volumes of milk with (ACM) or without (NAM) acid.

\begin{tabular}{llllll}
\hline $\begin{array}{l}\text { Variable and } \\
\text { comparison }\end{array}$ & Coefficient & SEM & $\mathrm{OR}^{\mathrm{b}}$ & $95 \% \mathrm{Cl}^{\mathrm{c}}$ & $P$-value \\
\hline
\end{tabular}

Fecal score $>2$

$\begin{array}{llllll}\text { MOD vs. } \mathrm{HIGH} & -0.1989 & 0.13 & 0.82 & 0.635-1.058 & 0.13\end{array}$

$\begin{array}{llllll}\text { NAM vs. ACM } & 0.2736 & 0.13 & 1.32 & 1.018-1.698 & 0.04\end{array}$

a Fecal score: 1 to 5, 1 = firm, 2 = soft or of moderate consistency, $3=$ runny or mild diarrhea and $4=$ watery and profuse diarrhea.

${ }^{b}$ The odds ratio $(O R)$ indicates the probability of having diarrhea $(>2)$ in calves fed $M O D$ vs. HIGH, or milk with (ACM) vs. without (NAM) acid. If the $O R$ is $>1$, a given treatment in the comparison is more likely to have experience diarrhea than the other treatment by a factor of the difference above 1.

${ }^{c} \mathrm{Cl}$, confidence interval for the odds ratio, include lower and upper confidence limit.

who fed their calves $4 \mathrm{~L} / \mathrm{d}$ of milk preweaning, calves consumed around $130 \mathrm{~g} / \mathrm{d}$ of oat hay postweaning, implying that calves could eat even more hay than the amount provided. However, care should be taken when hay is provided at a greater rate of 5$10 \%$ of DM due to the possibility of gut fill (Imani et al., 2017), which can have detrimental effects on ADG.

Our hypothesis was rejected because compared to calves fed NAM, the growth of the calves fed ACM was negatively affected in this study, specifically from days 49 to 78 (end of study) resulting in lower BW. The differences were difficult to explain, though previous studies have indicated that decreasing the $\mathrm{pH}$ of MR below 4.5 is likely to affect MR intakes (Todd et al., 2018) and the growth of gut epithelium (Zhang et al., 2017), which in turn may affect the absorption of nutrients. Acidification of milk at a $\mathrm{pH}$ ranging from 4.3 to 4.5 in our experiment, in combination with lower milk intake, might have contributed to the compromised growth performance over the weaning period, affecting absorption of feed substrates reaching the intestines for calves fed ACM. Growth rates were similar for both groups of MOD calves, while ACM-HIGH generally had lower growth rates than NAM-HIGH until day 42 (Figure 2). This affirms our assumption that amount of acid consumed might have affected the gut epithelium, which compounded with weaning stress, further slowed down the growth in calves fed ACM. Our results are contrary to previous studies, which 
have shown that ACM neither reduces nor promotes overall growth rates in calves (Hill et al., 2013; Todd et al., 2016). It should be noted that the aforementioned studies utilized MRs. Furthermore, during weaning, Hill et al. (2013) fed calves NAM. Whether this could have contributed to reducing the negative effects of milk acidification during the weaning process is not clear. What was clear from their study was that feeding calves at 4.2 compared to $5.2 \mathrm{pH}$ tended to lower growth during preweaning. Although, no studies have compared between feeding ACM and MR, the type of milk diet might influence the effect of organic acids on the growth performance, as has been suggested for butyrate (Górka et al., 2018). Investigating the effects of feeding ACM on gut epithelium was beyond our scope and further studies are warranted, especially with lower $\mathrm{pH}$ of acidified whole milk. However, the overall ADG in our study was within ranges $(0.61-0.78 \mathrm{~kg} / \mathrm{d})$ reported in a previous study in calves fed acidified whole milk above $6 \mathrm{~L} / \mathrm{d}$ (Huuskonen et al., 2011). In another large study, conducted over a period of 1 year, Todd et al. (2017) reported relatively lower ADG in calves fed ad libitum $(0.59 \mathrm{~kg} / \mathrm{d})$ formic acidified MR compared to restricted $(0.43 \mathrm{~kg} / \mathrm{d} ; 6 \mathrm{~L} / \mathrm{d})$ fed calves, though they did not report the amount consumed by the former group.

The amount of milk fed had a positive effect on the growth of calves, especially during the first 42 days. Due to greater ADG in calves fed high milk volumes, the NAM and ACM calves were heavier compared to their counterparts. Due to pseudomonogastric gut anatomy, the calf depends mainly on milk as a source of energy in the first 21 days of age (NRC, 2001) and an increase in BW is dependent on the volume of milk fed or total ME supplied (Drackley, 2008). Hence, the differences in BW observed at the early age were a result of the milk being able to supply extra energy above what is required for maintenance and growth [e.g. NAM-MOD $=4.6$ vs. NAM-HIGH $=7.8 \mathrm{MCal} / \mathrm{d}$ in the first 42 days of life]. We observed a significant decrease in the ADG between the beginning of weaning and day 63, which was more severe in calves fed greater milk volumes. The greater slump in $\mathrm{ADG}$ during the weaning transition is a common phenomenon in calves receiving high volumes of milk (Jasper and Weary, 2002; de Passillé et al., 2011; Stamey et al., 2012), especially if stepdown weaning strategy is not adequate (Frieten et al., 2017; Steele et al., 2017). This reduction in growth around the weaning period with increased starter intake has been attributed to a reduction in the digestibility of nutrients in the same period (Dennis et al., 2018; Quigley et al., 2018). The NAM-MOD calves might have had a more developed rumen able to digest the starter and provide energy substrates in the form of VFA for growth (Baldwin et al., 2004; Quigley et al., 2018). Postweaning transition growth rates tended to be similar between treatments indicating that the HIGH fed calves recovered from the adverse effects of weaning on the gut. Hence, the differences in BW persisted even after weaning (Jasper and Weary, 2002), which is typical for calves weaned at a comparable older age (de Passillé et al., 2011). The preweaning growth rates contribute to the greater BW-measured postweaning in calves fed high as opposed to moderate milk volumes (Hu et al., 2020). It is also important to note that calves receiving high compared to moderate volume of milk in this study had relatively low overall ADG. Although, we believe that, the weaning strategy contributed greatly to the reduced ADG, we also suggest that hay feeding and type of calf starter might have partly been responsible for the reduced growth. In a companion study, but under different treatments (calves were fed $8 \mathrm{~L} / \mathrm{d}$ from days 7 to 42 ) calves that were fed hay had greater overall ADG compared to those that were fed calf starter only (Chen et al., 2021). Calves also require optimal CP-to-energy ratios for maximum growth. Calves fed above $6 \mathrm{~L} / \mathrm{d}$ of milk might have required greater amount of $\mathrm{CP}$ in their calf starter to be able to keep supporting the preweaning high growth rates during weaning and upon milk withdrawal (Yousefinejad et al., 2021).

Overall the feed efficiency was higher in calves receiving moderate volumes of milk in our trial. Previous studies have shown that calves fed greater volumes of milk or MRs tend to have greater feed efficiencies compared to calves receiving around $10 \%$ of the calf BW (Diaz et al., 2001; Khan et al., 2007b; Omidi-Mirzaei et al., 2015), whereas others were not different (Rosenberger et al., 2017). However, unlike Khan et al. (2007b) who reported consistently higher feed efficiency in their study including during the weaning stage, calves on high milk volumes had lower FE compared to the moderate calves during days 5063 in our study. The observed differences around the weaning period in our study could be attributed to a greater decrease in ADG with a concomitant greater total DMI (Diaz et al., 2001).

Structural growth measurements including length, heart girth, and abdominal girth were affected by milk volume mainly, such that calves fed high volumes had larger body size, especially in the preweaning period. Calves are expected to increase in body weight concomitantly with structural growth (Heinrichs et al., 1992). The calf uses extra energy from higher milk volume for tissue gain and skeletal growth (NRC, 2001; Hu et al., 2020). Milk volume and milk acidification independently affected the structural measurements in a similar manner to BW. An increase in body measurements in response to higher milk volume has been previously reported (Khan et al., 2007a; OmidiMirzaei et al., 2015). No differences were observed in structural measurements in relation to feeding ACM, except for a decrease in heart girth on day 78 .

Serum glucose is dependent on the age of the calf and energy density from milk or MR in the preweaning period. Generally, glucose level decreases with the development of the rumen since the energy substrates shifts from glucose absorbed from milk to VFA (Baldwin et al., 2004). Glucose homeostasis can be affected by both feeding frequency and feeding level. The greater milk consumed on day 28 by HIGH calves could have resulted in greater lactose intake (Mirzaei et al., 2018), which in turn influences the glucose level in the blood. This was consistent with glucose concentration dropping and being similar from day 49 after the high-fed calves milk intake was reduced on day 42. The concentration of insulin is dependent on energy intake. Differential concentration is inevitable in the preweaning period between calves fed low and high volumes of milk (Hammon et al., 2002). High volumes of liquid feed may result in higher insulin in response to glucose in the blood (Frieten et al., 2017). However, the calves can become insensitive to insulin and hence not utilize the glucose available in the blood. We, therefore, 
speculate that feeding calves with high milk volumes could have led to temporal insulin insensitivity. Some authors have suggested that increased milk intake might lead to increased adiposity concomitant with a decrease in insulin sensitivity (Bach et al., 2013). Plasma NEFA is a biomarker for lipid mobilization in young calves. Our results showed that there were no differences between different levels of milk feeding, indicating that fat mobilization was similar for the same milk feeding level groups (Maccari et al., 2015). Some studies have reported that high plasma NEFA can also be observed in high milk volume fed calves (Byrne et al., 2018) due to increased fat mobilization just before morning feeding (Kmicikewycz et al., 2013). Few studies have investigated the effect of high nutrient supply on the adipose tissue. Leal et al. (2018) reported that the adipose transcriptome at 54 days was altered by enhanced MR feeding and could process NEFA at a higher rate compared to restricted feeding. The capacity of adipose tissue to synthesize NEFA has been reported to be greater in steers than calves (Howarth et al., 1968). Since this study was done at a later date, compared to the earliest time point, we sampled blood, direct linking of our data to theirs was done with care. However, the lack of differences in NEFA might be indicative of the adipose tissue being readily active at an early age in calves, which resulted in calves being able to produce similar amounts just before the next meal in the morning.

Total protein and PUN can be used as indicators of protein metabolism. The milk feeding strategy did not affect the protein level during the milk feeding period, indicating that these calves had the same efficiency in utilizing the protein available in the milk diet. Our values were within ranges reported in the literature for preweaning calves of the same age (Omidi-Mirzaei et al., 2015; Alugongo et al., 2017), but slightly lower than others (Mirzaei et al., 2018). Calves that received high milk volumes tended to have a higher total protein level in the blood on day 78, which could be reflective of the tendency of earlier MOD calves having increased nitrogen utilization or retention of protein in tissues (Byrne et al., 2018). The milk feeding strategy and day interaction for the PUN in our calves could be associated with a decrease on day 49 , followed by an increase after complete weaning in all groups. This can be attributed to the greater starter intake and its ruminal degradation after complete weaning from milk, which leads to greater ammonia production in the rumen (Khan et al., 2007a).

The IGF-1 concentration was not affected by either treatment or age of the calf. Although IGF-1 is expected to increase with energy intake, some studies have reported that IGF-1 can be lower in calves receiving high volumes of milk (Hammon et al., 2002). Inconsistent with previous studies, our calves had a similar concentration of IGF-1 during the different feeding periods. In MR-fed calves, it has been suggested that IGF-1 might not be directly influenced by greater nutrient supply (Bartlett et al., 2006). Milk feeding strategy and acidification did not affect CCK, a gut regulatory peptide that responds to diet in the gut. The CCK tends to increase $3 \mathrm{~h}$ after a meal (Guilloteau et al., 2010), and lack of differences could be ascribed to our sampling time that was done before the morning meal and at least after $10 \mathrm{~h}$ in the high milk volume feeding.
The physiological status of the calves during the weaning process can be destabilized by the withdrawal of liquid feed and the introduction of solid feed, as the calves are not completely ready to utilize rumen fermentation products for growth and defense against infections. Hence, the immune system is likely to be compromised. The body requires an active immunity defense mechanism to defend itself against foreign bodies. The immune system produces oxidants that need to be removed from the body during the same period. Oxidative biomarkers (GSH-Px, SOD, MDA, and TAOC) are critical in balancing the physiology of the calf and hence keeping the calf in good health condition. In the present experiment, the oxidative biomarker concentrations were within the ranges that have been reported in previous trials (Alugongo et al., 2017; Zou et al., 2017). Under the conditions of our experiment, calves fed ACM might have experienced some oxidative stress postweaning (Wang et al., 2018). However, the greater TAOC levels in NAM-fed calves implies the need for supplementation of antioxidants in young calves during early life (Abuelo et al., 2014).

The preweaning period poses the greatest risk in terms of mortality and morbidity (Windeyer et al., 2014) with enteric infections being a serious risk factor (Svensson et al., 2003). Therapeutic interventions, especially the use of antibiotics in the food industry, remain a major concern for the human population (Witte, 1998; Wemette et al., 2021). Lower incidences of diarrhea are likely to translate in less treatments with antibiotics (Kaya et al., 2000; Güler et al., 2006), which could contribute to healthy animals as well as the reduction in antimicrobial-resistant bacteria in the environment. Reports on the effect of milk or MR volumes fed to calves on their health are not conclusive. Some have reported increased (Dennis et al., 2018) whereas others have reported fewer or similar (Jasper and Weary, 2002; Khan et al., 2007a) incidences of diarrhea compared to calves provided low to moderate volumes of milk. Consistent with Khan et al. (2007a), we observed a similar likelihood of diarrhea in calves fed either moderate or high volumes of milk. On the other hand, similar to the work of Bush and Nicholson (1987), ACM feeding showed a potential to lower likelihood of diarrhea when compared to feeding NAM in the preweaning period. We speculate that the acid can kill or lower the pathogenic bacteria in the milk as well as harmful bacteria in the gut, while allowing the good bacteria to flourish (Anderson, 2008; Deng et al., 2017). The low milk $\mathrm{pH}$ keeps the abomasal $\mathrm{pH}$ closer to preprandial values $(\mathrm{pH}<$ 2.0 in milk fed calves), especially if fed at higher frequencies (Constable et al., 2006; Burgstaller et al., 2017). However, we did not determine the diarrhea-causing fecal microbiota in this study, and more research is required to prove our speculations. Although the potential decrease in morbidity did not result in improved growth, as discussed earlier, the $\mathrm{pH}$ of the milk utilized in our study could have interfered with the gut morphology. Fewer studies have investigated the effect of feeding whole ACM on calf health and gut development. Future studies are required to determine the impact of ACM pH level on calf growth, especially in light of its apparent adverse effect on the gut (Zhang et al., 2017). Moreover, our study provides a proof of concept that milk acidification reduces the likelihood of experiencing diarrhea in calves independent of the amount of milk fed. 
Hence a larger study with more animals is needed to determine whether milk acidification can affect the incidences of diarrhea in calves.

\section{CONCLUSION}

The results suggested that feeding high compared to moderate volumes of milk did not improve the overall growth of calves in this study. This effect of milk feeding strategy was partly due to the relatively abrupt weaning protocol applied, which allowed moderate-fed calves to compensate for their low growth during the first 56 days of life. However, calves fed high compared to moderate volume of milk maintained a greater body weight from day 28 to the end of study on day 78 as a result of the growth rates experienced in the first 42 days of life. In line with greater growth in the first month of life, our findings also showed that glucose concentration was greater in calves fed high volumes of milk on day 28 only. Milk acidification may reduce the growth despite lowering the likelihood of calves experiencing diarrhea and not disrupting the metabolic and oxidative stress biomarkers. A combination of feeding strategy and milk acidification did not seem to affect any of the parameters investigated. Future studies with a greater number of animals should consider examining the effect of feeding formic ACM at $\mathrm{pH}$ levels lower than 4.5 on gut morphology and nutrient intake in calves.

\section{DATA AVAILABILITY STATEMENT}

The original contributions presented in the study are included in the article/supplementary material, further inquiries can be directed to the corresponding author.

\section{REFERENCES}

Abuelo, Á., Pérez-Santos, M., Hernández, J., and Castillo, C. (2014). Effect of colostrum redox balance on the oxidative status of calves during the first 3 months of life and the relationship with passive immune acquisition. Vet. J. 199, 295-299. doi: 10.1016/j.tvjl.2013.10.032

Alugongo, G. M., Xiao, J. X., Chung, Y. H., Dong, S. Z., Li, S. L., Yoon, I., et al. (2017). Effects of Saccharomyces cerevisiae fermentation products on dairy calves: performance and health. J. Dairy Sci. 100, 1189-1199. doi: 10.3168/jds.2016-11399

Anderson, N. G. (2008). "Experiences with free-access acidified-milk feeding in Ontario," in American Association of Bovine Practitioners Proceedings of the Annual Conference, 12-24. Available online at: http://www.dairyweb.ca/ Resources/AABP2008/Anderson.pdf (accessed January 16, 2021).

Bach, A., Domingo, L., Montoro, C., and Terré, M. (2013). Short communication: Insulin responsiveness is affected by the level of milk replacer offered to young calves. J. Dairy Sci. 96, 4634-4637. doi: 10.3168/jds.2012-6196

Baldwin, V. I. R. L., McLeod, K. R., Klotz, J. L., and Heitmann, R. N. (2004). Rumen development, intestinal growth and hepatic metabolism in the pre- and postweaning ruminant. J. Dairy Sci. 87, E55-65. doi: 10.3168/jds.S0022-0302(04)70061-2

Bartlett, K. S., McKeith, F. K., VandeHaar, M. J., Dahl, G. E., and Drackley, J. K. (2006). Growth and body composition of dairy calves fed milk replacers containing different amounts of protein at two feeding rates1. J. Anim. Sci. 84, 1454-1467. doi: $10.2527 / 2006.8461454 \mathrm{x}$

\section{ETHICS STATEMENT}

The animal study was reviewed and approved by Ethical Committee of the College of Animal Science and Technology of China Agricultural University.

\section{AUTHOR CONTRIBUTIONS}

GA conceived and designed the experiment, managed the calves, analyzed data, and wrote original draft. ZC conceived, designed the experiment, and funding acquisition. YM and SLiu managed the calves and collected the data. JX analyzed the data. AA helped in data analysis and interpretation. SLi and YW offered critiques and suggestions on the manuscript. All authors contributed to the article and approved the submitted version.

\section{FUNDING}

The research was supported by the National Key Research and Development Program of China (2021YFF1000703-03) and the 2115 Talent Development Program of China Agricultural University.

\section{ACKNOWLEDGMENTS}

The authors would like to thank the management of Zhong Yuan Dairy Farm (Xinle, Hebei, China) for providing their facilities and animals for this study. We also appreciate the help and technical assistance of their staff, who assisted in feeding and caring for the calves. We also appreciate Ma Jing, Li Tingting, Liu Hao and Xue Guopeng who helped feed the calves and collect samples.

Benetton, J. B., Neave, H. W., Costa, J. H. C., von Keyserlingk, M. A. G., and Weary, D. M. (2019). Automatic weaning based on individual solid feed intake: effects on behavior and performance of dairy calves. J. Dairy Sci. 102, 5475-5491. doi: 10.3168/jds.2018-15830

Burgstaller, J., Wittek, T., and Smith, G. W. (2017). Invited review: abomasal emptying in calves and its potential influence on gastrointestinal disease. $J$. Dairy Sci. 100, 17-35. doi: 10.3168/jds.2016-10949

Bush, R. S., and Nicholson, J. W. G. (1987). Effect of two acids and formalin in calves milk on feed consumption and performance. Can. J. Anim. Sci. 67, 1129-1131. doi: 10.4141/cjas87-119

Byrne, C. J., Fair, S., English, A. M., Urh, C., Sauerwein, H., Crowe, M. A., et al. (2018). Plane of nutrition before and after 6 months of age in HolsteinFriesian bulls: II. Effects on metabolic and reproductive endocrinology and identification of physiological markers of puberty and sexual maturation. $J$. Dairy Sci. 101, 3460-3475. doi: 10.3168/jds.2017-13720

Castells, L., Bach, A., Araujo, G., Montoro, C., and Terré, M. (2012). Effect of different forage sources on performance and feeding behavior of Holstein calves. J. Dairy Sci. 95, 286-293. doi: 10.3168/jds.2011-4405

Castells, L., Bach, A., Aris, A., and Terré, M. (2013). Effects of forage provision to young calves on rumen fermentation and development of the gastrointestinal tract. J. Dairy Sci. 96, 5226-5236. doi: 10.3168/jds.2012-6419

Chen, T., Xiao, J., Li, T., Ma, J., Alugongo, G. M., Khan, M. Z., et al. (2021) Effect of the initial time of providing oat hay on performance, health, behavior and rumen fermentation in holstein female calves. Agriculture 11, 862. doi: 10.3390/agriculture11090862 
Constable, P. D., Wittek, T., Ahmed, A. F., Marshall, T. S., Sen, I., and Nouri, M. (2006). "Abomasal pH and emptying rate in the calf and dairy cow and the effect of commenly administred therapeutic agents," in World Buiatrics Congress 2, 15

Costa, J. H. C., Cantor, M. C., Adderley, N. A., and Neave, H. W. (2019). Key animal welfare issues in commercially raised dairy calves: social environment, nutrition, and painful procedures. Can. J. Anim. Sci. 99. doi: 10.1139/cjas-2019-0031

DCHA (2016). Dairy Calf and Heifer Association Gold Standards: Setting the Benchmarks for Your Herd's future. Available online at: http://haasnutrition. com/wp-content/uploads/2015/09/DCHA_GoldStandards_high-res_122016. pdf (accessed October 28, 2021).

de Passillé, A. M., Borderas, T. F., and Rushen, J. (2011). Weaning age of calves fed a high milk allowance by automated feeders: effects on feed, water, and energy intake, behavioral signs of hunger, and weight gains. J. Dairy Sci. 94, 1401-1408. doi: 10.3168/jds.2010-3441

de Passillé, A. M., and Rushen, J. (2016). Using automated feeders to wean calves fed large amounts of milk according to their ability to eat solid feed. J. Dairy Sci. 99, 3578-3583. doi: 10.3168/jds.2015-10259

Deng, Y. F., Wang, Y. J., Zou, Y., Azarfar, A., Wei, X. L., Ji, S. K., et al. (2017). Influence of dairy by-product waste milk on the microbiomes of different gastrointestinal tract components in pre-weaned dairy calves. Sci. Rep. 7, 42689. doi: $10.1038 / \mathrm{srep} 42689$

Dennis, T. S., Suarez-Mena, F. X., Hill, T. M., Quigley, J. D., Schlotterbeck, R. L., and Hulbert, L. (2018). Effect of milk replacer feeding rate, age at weaning, and method of reducing milk replacer to weaning on digestion, performance, rumination, and activity in dairy calves to 4 months of age. J. Dairy Sci. 101, 268-278. doi: 10.3168/jds.2017-13692

Diaz, M. C., Van Amburgh, M. E., Smith, J. M., Kelsey, J. M., and Hutten, E. L. (2001). Composition of growth of Holstein calves fed milk replacer from birth to 105 -kilogram body weight. J. Dairy Sci. 84, 830-842. doi: 10.3168/jds.S0022-0302(01)74541-9

Drackley, J. K. (2008). Calf nutrition from birth to breeding. Vet. Clin. North Am. Food Anim. Pract. 24, 55-86. doi: 10.1016/j.cvfa.2008.01.001

Du, W., Hou, F., Tsunekawa, A., Kobayashi, N., Ichinohe, T., and Peng, F. (2019). Effects of the diet inclusion of common vetch hay versus alfalfa hay on the body weight gain, nitrogen utilization efficiency, energy balance, and enteric methane emissions of crossbred simmental cattle. Animals 9, 983. doi: 10.3390/ani9110983

Eckert, E., Brown, H. E., Leslie, K. E., DeVries, T. J., and Steele, M. A. (2015). Weaning age affects growth, feed intake, gastrointestinal development, and behavior in Holstein calves fed an elevated plane of nutrition during the preweaning stage. J. Dairy Sci. 98, 6315-6326. doi: 10.3168/jds.2014-9062

Engelking, L. E., Matsuba, T., Inouchi, K., Sugino, T., and Oba, M. (2020). Effects of feeding hay and calf starter as a mixture or as separate components to Holstein calves on intake, growth, and blood metabolite and hormone concentrations. J. Dairy Sci. 103, 4423-4434. doi: 10.3168/jds.2019-17676

Frieten, D., Gerbert, C., Koch, C., Dusel, G., Eder, K., Kanitz, E., et al. (2017). Ad libitum milk replacer feeding, but not butyrate supplementation, affects growth performance as well as metabolic and endocrine traits in Holstein calves. $J$. Dairy Sci. 100, 6648-6661. doi: 10.3168/jds.2017-12722

Gelsinger, S. L., Heinrichs, A. J., and Jones, C. M. (2016). A meta-analysis of the effects of preweaned calf nutrition and growth on first-lactation performancel. J. Dairy Sci. 99, 6206-6214. doi: 10.3168/jds.2015-10744

Górka, P., Kowalski, Z. M., Zabielski, R., and Guilloteau, P. (2018). Invited review: use of butyrate to promote gastrointestinal tract development in calves. J. Dairy Sci. 101, 4785-4800. doi: 10.3168/jds.2017-14086

Guilloteau, P., Savary, G., Jaguelin-Peyrault, Y., Romé, V., Le Normand, L., and Zabielski, R. (2010). Dietary sodium butyrate supplementation increases digestibility and pancreatic secretion in young milk-fed calves. J. Dairy Sci. 93, 5842-5850. doi: 10.3168/jds.2009-2751

Güler, O., Yanar, M., Bayram, B., and Metin, J. (2006). Performance and health of dairy calves fed limited amounts of acidified milk replacer. South African J. Anim. Sci. 36, 149-154. Available online at: https://journals.co.za/doi/abs/10. 10520/EJC94493

Hammon, H. M., Schiessler, G., Nussbaum, A., and Blum, J. W. (2002). Feed intake patterns, growth performance, and metabolic and endocrine traits in calves fed unlimited amounts of colostrum and milk by automate, starting in the neonatal period. J. Dairy Sci. 85, 3352-3362. doi: 10.3168/jds.S0022-0302(02)74423-8
Heinrichs, A. J., Rogers, G. W., and Cooper, J. B. (1992). Predicting body weight and wither height in holstein heifers using body measurements. J. Dairy Sci. 75, 3576-3581. doi: 10.3168/jds.S0022-0302(92)78134-X

Hill, T. M., Bateman, H. G., Aldrich, J. M., Quigley, J. D., and Schlotterbeck, R. L. (2013). Evaluation of ad libitum acidified milk replacer programs for dairy calves. J. Dairy Sci. 96, 3153-3162. doi: 10.3168/jds.2012-6132

Howarth, R. E., Baldwin, R. L., and Ronning, M. (1968). Enzyme activities in liver, muscle, and adipose tissue of calves and steers. J. Dairy Sci. 51, 1270-1274. doi: 10.3168/jds.S0022-0302(68)87170-X

Hu, W., Hill, T. M., Dennis, T. S., Suarez-Mena, F. X., Aragona, K. M., Quigley, J. D., et al. (2020). Effects of milk replacer feeding rates on growth performance of Holstein dairy calves to 4 months of age, evaluated via a meta-analytical approach. J. Dairy Sci. 103, 2217-2232. doi: 10.3168/jds.2019-17206

Huber, J. T. (1969). Development of the digestive and metabolic apparatus of the calf. J. Dairy Sci. 52, 1303-1315. doi: 10.3168/jds.S0022-0302(69)86744-5

Huber, J. T., Silva, A. G., Campos, O. F., and Mathieu, C. M. (1984). Influence of feeding different amounts of milk on performance, health, and absorption capability of baby calves. J. Dairy Sci. 67, 2957-2963. doi: 10.3168/jds.S0022-0302(84)81659-8

Huuskonen, A., Huumonen, M., Joki-Tokola, E., and Tuomisto, L. (2011). Effects of different liquid feeding strategies during the pre-weaning period on the performance and carcass characteristics of dairy bull calves. Acta Agric. Scand. A Anim. Sci. 61, 187-195. doi: 10.1080/09064702.2011.645863

Imani, M., Mirzaei, M., Baghbanzadeh-Nobari, B., and Ghaffari, M. H. (2017). Effects of forage provision to dairy calves on growth performance and rumen fermentation: a meta-analysis and meta-regression. J. Dairy Sci. 100, 1136-1150. doi: 10.3168/jds.2016-11561

Jasper, J., and Weary, D. M. (2002). Effects of ad libitum milk intake on dairy calves. J. Dairy Sci. 85, 3054-3058. doi: 10.3168/jds.S0022-0302(02)74391-9

Kaya, A., Uzmay, C., Alçiçek, A., and Kaya, I. (2000). A research on rearing calves with acidified whole milk. Turkish J. Vet. Anim. Sci. 24, 413-421

Khan, M. A., Lee, H. J., Lee, W. S., Kim, H. S., Ki, K. S., Hur, T. Y., et al. (2007a). Structural growth, rumen development, and metabolic and immune responses of holstein male calves fed milk through step-down and conventional methods. J. Dairy Sci. 90, 3376-3387. doi: 10.3168/jds.2007-0104

Khan, M. A., Lee, H. J., Lee, W. S., Kim, H. S., Kim, S. B., Ki, K. S., et al. (2007b). Pre- and postweaning performance of holstein female calves fed milk through step-down and conventional methods. J. Dairy Sci. 90, 876-885. doi: 10.3168/jds.S0022-0302(07)71571-0

Khan, M. A., Weary, D. M., and von Keyserlingk, M. A. G. (2011). Invited review: effects of milk ration on solid feed intake, weaning, and performance in dairy heifers. J. Dairy Sci. 94, 1071-1081. doi: 10.3168/jds.2010-3733

Kiezebrink, D. J., Edwards, A. M., Wright, T. C., Cant, J. P., and Osborne, V. R. (2015). Effect of enhanced whole-milk feeding in calves on subsequent firstlactation performance. J. Dairy Sci. 98, 349-356. doi: 10.3168/jds.2014-7959

Klopp, R. N., Suarez-Mena, F. X., Dennis, T. S., Hill, T. M., Schlotterbeck, R. L., and Lascano, G. J. (2019). Effects of feeding different amounts of milk replacer on growth performance and nutrient digestibility in Holstein calves to 2 months of age using different weaning strategies. J. Dairy Sci. 102, 11040-11050. doi: 10.3168/jds.2019-17153

Kmicikewycz, A. D., da Silva, D. N. L., Linn, J. G., and Litherland, N. B. (2013). Effects of milk replacer program fed 2 or 4 times daily on nutrient intake and calf growth1. J. Dairy Sci. 96, 1125-1134. doi: 10.3168/jds.2012-5738

Leal, L. N., Romao, J. M., Hooiveld, G. J., Soberon, F., Berends, H., Boekshoten, M. V., et al. (2018). Nutrient supply alters transcriptome regulation in adipose tissue of pre-weaning Holstein calves. PLoS ONE 13, 1-17. doi: 10.1371/journal.pone.0201929

Lorenz, I., Huber, R., and Trefz, F. M. (2021). A high plane of nutrition is associated with a lower risk for neonatal calf diarrhea on bavarian dairy farms. Animals 11 , 1-11. doi: 10.3390/ani11113251

Maccari, P., Wiedemann, S., Kunz, H.-J., Piechotta, M., Sanftleben, P., and Kaske, M. (2015). Effects of two different rearing protocols for Holstein bull calves in the first 3 weeks of life on health status, metabolism and subsequent performance. J. Anim. Physiol. Anim. Nutr. 99, 737-746. doi: 10.1111/jpn.12241

Magalhães, V. J. A., Susca, F., Lima, F. S., Branco, A. F., Yoon, I., and Santos, J. E. P. (2008). Effect of feeding yeast culture on performance, health, and immunocompetence of dairy calves. J. Dairy Sci. 91, 1497-1509. doi: 10.3168/jds.2007-0582 
Mirzaei, M., Dadkhah, N., Baghbanzadeh-Nobari, B., Agha-Tehrani, A., Eshraghi, M., Imani, M., et al. (2018). Effects of preweaning total plane of milk intake and weaning age on intake, growth performance, and blood metabolites of dairy calves. J. Dairy Sci. 101, 4212-4220. doi: 10.3168/JDS.2017-13766

Moallem, U., Werner, D., Lehrer, H., Zachut, M., Livshitz, L., Yakoby, S., et al. (2010). Long-term effects of ad libitum whole milk prior to weaning and prepubertal protein supplementation on skeletal growth rate and first-lactation milk production. J. Dairy Sci. 93, 2639-2650. doi: 10.3168/jds.2009-3007

Neave, H. W., Costa, J. H. C., Benetton, J. B., Weary, D. M., and von Keyserlingk, M. A. G. (2019). Individual characteristics in early life relate to variability in weaning age, feeding behavior, and weight gain of dairy calves automatically weaned based on solid feed intake. J. Dairy Sci. 102, 10250-10265. doi: 10.3168/jds.2019-16438

Nocek, J. E., and Braund, D. G. (1986). Performance, health, and postweaning growth on calves fed cold, acidified milk replacer ad libitum. J. Dairy Sci. 69, 1871-1883. doi: 10.3168/jds.S0022-0302(86)80613-0

NRC (2001). Nutrient Requirements of Dairy Cattle. 7th revise. Washington, D.C.: National Academies Press doi: 10.17226/9825

Omidi-Mirzaei, H., Khorvash, M., Ghorbani, G. R., Moshiri, B., Mirzaei, M., Pezeshki, A., et al. (2015). Effects of the step-up/step-down and step-down milk feeding procedures on the performance, structural growth, and blood metabolites of Holstein dairy calves. J. Dairy Sci. 98, 7975-7981. doi: 10.3168/jds.2014-9260

Overvest, M. A., Bergeron, R., Haley, D. B., and DeVries, T. J. (2016). Effect of feed type and method of presentation on feeding behavior, intake, and growth of dairy calves fed a high level of milk. J. Dairy Sci. 99, 317-327. doi: $10.3168 /$ jds.2015-9997

Parker, A. M., House, J. K., Hazelton, M. S., Bosward, K. L., Mohler, V. L., Maunsell, F. P., et al. (2016). Milk acidification to control the growth of Mycoplasma bovis and Salmonella Dublin in contaminated milk. J. Dairy Sci. 99, 9875-9884. doi: 10.3168/jds.2016-11537

Quigley, J. D., Hill, T. M., Dennis, T. S., Suarez-Mena, F. X., and Schlotterbeck, R. L. (2018). Effects of feeding milk replacer at 2 rates with pelleted, low-starch or texturized, high-starch starters on calf performance and digestion. J. Dairy Sci. 101, 5937-5948. doi: 10.3168/jds.2017-13851

Quigley, J. D., Hu, W., Knapp, J. R., Dennis, T. S., Suarez-Mena, F. X., and Hill, T. M. (2019). Estimates of calf starter energy affected by consumption of nutrients. 2. Effect of changing digestion on energy content in calf starters. J. Dairy Sci. 102, 2242-2253. doi: 10.3168/jds.2018-15354

Richard, A. L., Muller, L. D., and Heinrichs, A. J. (1988). Ad libitum or twice daily feeding of acidified milk replacer to calves housed individually in warm and cold environments. J. Dairy Sci. 71, 2193-2202. doi: 10.3168/jds.S0022-0302(88)79793-3

Rosenberger, K., Costa, J. H. C., Neave, H. W., von Keyserlingk, M. A. G., and Weary, D. M. (2017). The effect of milk allowance on behavior and weight gains in dairy calves. J. Dairy Sci. 100, 504-512. doi: 10.3168/jds.2016-11195

Roth, B. A., Keil, N. M., Gygax, L., and Hillmann, E. (2009). Influence of weaning method on health status and rumen development in dairy calves. J. Dairy Sci. 92, 645-656. doi: 10.3168/jds.2008-1153

Soberon, F., Raffrenato, E., Everett, R. W., and Van Amburgh, M. E. (2012). Preweaning milk replacer intake and effects on long-term productivity of dairy calves. J. Dairy Sci. 95, 783-793. doi: 10.3168/jds.2011-4391

Stamey, J. A., Janovick, N. A., Kertz, A. F., and Drackley, J. K. (2012). Influence of starter protein content on growth of dairy calves in an enhanced early nutrition program. J. Dairy Sci. 95, 3327-3336. doi: 10.3168/jds.2011-5107

Steele, M. A., Doelman, J. H., Leal, L. N., Soberon, F., Carson, M., and Metcalf, J. A. (2017). Abrupt weaning reduces postweaning growth and is associated with alterations in gastrointestinal markers of development in dairy calves fed an elevated plane of nutrition during the preweaning period. J. Dairy Sci. 100, 5390-5399. doi: 10.3168/jds.2016-12310

Steinhoff-Wagner, J., Görs, S., Junghans, P., Bruckmaier, R. M., Kanitz, E., Metges, C. C., et al. (2011). Maturation of endogenous glucose production in preterm and term calves. J. Dairy Sci. 94, 5111-5123. doi: 10.3168/jds.2011-4355

Svensson, C., Lundborg, K., Emanuelson, U., and Olsson, S. O. (2003). Morbidity in Swedish dairy calves from birth to 90 days of age and individual calf-level risk factors for infectious diseases. Prev. Vet. Med. 58, 179-197. doi: 10.1016/S0167-5877(03)00046-1

Todd, C. G., Leslie, K. E., Millman, S. T., Bielmann, V., Anderson, N. G., Sargeant, J. M., et al. (2017). Clinical trial on the effects of a free-access acidified milk replacer feeding program on the health and growth of dairy replacement heifers and veal calves. J. Dairy Sci. 100, 713-725. doi: 10.3168/jds.2016-11401

Todd, C. G., Leslie, K. E., Millman, S. T., Sargeant, J. M., Migdal, H., Shore, K., et al. (2016). Milk replacer acidification for free-access feeding: effects on the performance and health of veal calves. Open J. Anim. Sci. 06, 234-246. doi: 10.4236/ojas.2016.63029

Todd, C. G., Millman, S. T., Leslie, K. E., Anderson, N. G., Sargeant, J. M., and DeVries, T. J. (2018). Effects of milk replacer acidification and free-access feeding on early life feeding, oral, and lying behavior of dairy calves. J. Dairy Sci. 101, 8236-8247. doi: 10.3168/jds.2018-14487

USDA (2016). Dairy Cattle Management Practices in the United States, 2014 Available online at: https://www.aphis.usda.gov/animal_health/nahms/dairy/ downloads/dairy14/Dairy14_dr_PartIII.pdf (accessed January 16, 2021).

van Niekerk, J. K., Fischer-Tlustos, A. J., Deikun, L. L., Quigley, J. D., Dennis, T. S., Suarez-Mena, F. X., et al. (2020). Effect of amount of milk replacer fed and the processing of corn in starter on growth performance, nutrient digestibility, and rumen and fecal fibrolytic bacteria of dairy calves. J. Dairy Sci. 103, 2186-2199. doi: 10.3168/jds.2019-17372

Wang, B., Yang, C. T., Diao, Q. Y., and Tu, Y. (2018). The influence of mulberry leaf flavonoids and Candida tropicalis on antioxidant function and gastrointestinal development of preweaning calves challenged with Escherichia coli O141:K99. J. Dairy Sci. 101, 6098-6108. doi: 10.3168/jds.2017-13957

Wemette, M., Safi, A. G., Welcome, F. L., Ivanek, R., and Shapiro, M. (2021). Public perceptions of antibiotic use on dairy farms in the United States. J. Dairy Sci. 104, 2807-2821. doi: 10.3168/jds.2019-17673

Windeyer, M. C., Leslie, K. E., Godden, S. M., Hodgins, D. C., Lissemore, K. D., and LeBlanc, S. J. (2014). Factors associated with morbidity, mortality, and growth of dairy heifer calves up to 3 months of age. Prev. Vet. Med. 113, 231-240. doi: 10.1016/j.prevetmed.2013.10.019

Witte, W. (1998). Medical consequences of antibiotic use in agriculture. Science 279, 996-997. doi: 10.1126/science.279.5353.996

Xiao, J. X., Guo, L. Y., Alugongo, G. M., Wang, Y. J., Cao, Z. J., and Li, S. L. (2018). Effects of different feed type exposure in early life on performance, rumen fermentation, and feed preference of dairy calves. J. Dairy Sci. 101, 8169-8181. doi: 10.3168/jds.2018-14373

Yousefinejad, S., Fattahnia, F., Kazemi-Bonchenari, M., Nobari, B., and Ghaffari, M. H. (2021). Effects of protein content and rumen-undegradable to rumendegradable protein ratio in finely ground calf starters on growth performance, ruminal and blood parameters, and urinary purine derivatives. J. Dairy Sci. 104, 8798-8813. doi: 10.3168/jds.2020-20092

Zhang, R., Diao, Q.-Y., Zhou, Y., Yun, Q., Deng, K.-D., Qi, D., et al. (2017). Decreasing the $\mathrm{pH}$ of milk replacer containing soy flour affects nutrient digestibility, digesta $\mathrm{pH}$, and gastrointestinal development of preweaned calves. J. Dairy Sci. 100, 236-243. doi: 10.3168/jds.201611374

Zou, Y., Wang, Y., Deng, Y., Cao, Z., Li, S., and Wang, J. (2017). Effects of feeding untreated, pasteurized and acidified waste milk and bunk tank milk on the performance, serum metabolic profiles, immunity, and intestinal development in Holstein calves. J. Anim. Sci. Biotechnol. 8, 1-11. doi: 10.1186/s40104-017-0182-4

Conflict of Interest: The authors declare that the research was conducted in the absence of any commercial or financial relationships that could be construed as a potential conflict of interest.

Publisher's Note: All claims expressed in this article are solely those of the authors and do not necessarily represent those of their affiliated organizations, or those of the publisher, the editors and the reviewers. Any product that may be evaluated in this article, or claim that may be made by its manufacturer, is not guaranteed or endorsed by the publisher.

Copyright (c) 2022 Alugongo, Xiao, Azarfar, Liu, Yousif, Ma, Wang, Li and Cao. This is an open-access article distributed under the terms of the Creative Commons Attribution License (CC BY). The use, distribution or reproduction in other forums is permitted, provided the original author(s) and the copyright owner(s) are credited and that the original publication in this journal is cited, in accordance with accepted academic practice. No use, distribution or reproduction is permitted which does not comply with these terms. 